\title{
The environmental impacts of human activities and engineering constructions in karst regions
}

\author{
Strumička 19, 11000 Beograd, Yugoslavia. E-mail: petar.mi@EUnet.yu
}

With increasing demands on water resources in karst regions, an important issue is how to keep the balance between the necessity for development and preservation of complex and unpredictable hydrogeological systems.

Karst terrains have been modified and adapted through a range of human activities as needs for drinking water, hydroelectric power and other resources increase. In many regions, reclamation projects, construction of large dams and reservoirs, deep underground excavations and complex foundation structures have had a detrimental impact on the environment. However, because each karst region is unique, the nature of environmental change is unpredictable, often occurs very rapidly, and similar situations are seldom, if ever, repeated.

Changes in karst function can have a profound impact on regional ecological, infrastructure, social and political systems. The majority of impacts can be foreseen and mitigated by appropriate designs. Ecological and environmental protection is more difficult when the changes are unexpected and source of problem is some distance from the impacted area. Optimal environmental protection requires a multidisciplinary approach, a lot of patience and perseverance, and adequate funds. Legal aspects and insurability are also very important basic elements in karst environmental protection. Criteria for determining the environmental protection, as well as regulatory procedures that are applicable for nonkarst regions are generally not suitable for karst terrain.

Successful solutions require serious and complex geological/hydrogeological investigation programs and close co-operation of a wide spectrum of scientists and engineers: geologists, civil engineers, biologists, chemists, hydrogeologists, geophysicists, sociologists and many others. In karst areas where interrelations and interactions are inadequately known, the ultimate aim is identification of crucial parameters that define causes and consequences between human activities and the resulting impact (cause-and-effect relations).

As a consequence of human activities and engineering construction in karst regions, the common negative environmental impacts are: severe spring discharge change, groundwater quality deterioration, endemic fauna endangering, waste disposal failures, induced seismicity, induced sinkholes, and a number of different secondary uncertainties. In some cases, socioeconomic problems related to migration from sub- merged regions are very pronounced. Similar problems are related with flooding of cultural and historical monuments and natural rarities. The major aims of proper planning of water resource systems in karst terrain are to minimize negative and to maximize positive environmental impacts. The optimal strategy of water resources development in karst areas is a key requirement for regional socio-economic development.

\section{Impact of large structures on karst aquifer and downstream springs}

Construction of large dams and reservoirs, the plugging of underground flows, the artificial drainage of flooded poljes, and the transfer of water from one catchment area to another change the natural conditions of both surface and groundwater flow paths. Such modification of water regime provokes considerable environmental impacts. The impacts include hydrogeological, hydrological, climatological, ecological and social changes.

In most instances, the impact is positive and predictable (flood reduction, irrigation, water supply improvement, power production, infrastructure improvement, reduction of deforestation and many secondary benefits). However, some impacts are negative and sometimes unpredictable: some important cultural and historical monuments and natural rarities are inundated, as well as arable land; the survival of endemic species is endangered; the population migrates from inundated areas; the regime of some aquifers and springs is changed, and induced collapse and subsidence occur.

Examples where complex dam construction has had significant environmental impact include: Tennessee Valey Project (USA); Trebisnjica Hydrosystem, Herzegovina (Yugoslavia); Gornja Zeta Project (Yugoslavia); Busko Blato, Bosnia (Yugoslavia); Sklope and Peruca Project (Croatia); Keban \& Ataturk Project (Turkey); dams at Karun River (Iran); Three Gorges Project (China); and other projects in Russia, Spain, Australia, Greece, Honduras, etc.

\section{Deterioration of aquifers}

With the construction of the complex power plant systems in Dinaric karst region, the recharge of the largest infiltration zones was reduced to specific, short-lasting, hydrological periods or completely blocked. Water is stored in reservoirs and transported through the tunnels and channels from high-elevated parts of catchment areas down to sea level. These structures have to be impervious. The flow into the aquifers through numerous ponors (swallow holes) has been removed (i.e. the recharge of karst aquifers has been eliminated).

The following examples illustrate the magnitude of this problem.

Trebisnjica Hydrosystem is one of the most complex projects in the Dinaric karst of East Herzegovina. Seven dams, six artificial reservoirs, six tunnels (with a total length of $57 \mathrm{~km}$ ), and four channels (with a total length of $74 \mathrm{~km}$ ) provide multi-purpose use of water resources from an elevation of $900 \mathrm{~m}$ a.s.l. Upon full completion, the natural regime of surface and groundwater will be completely changed (Figures 1 and 2). 


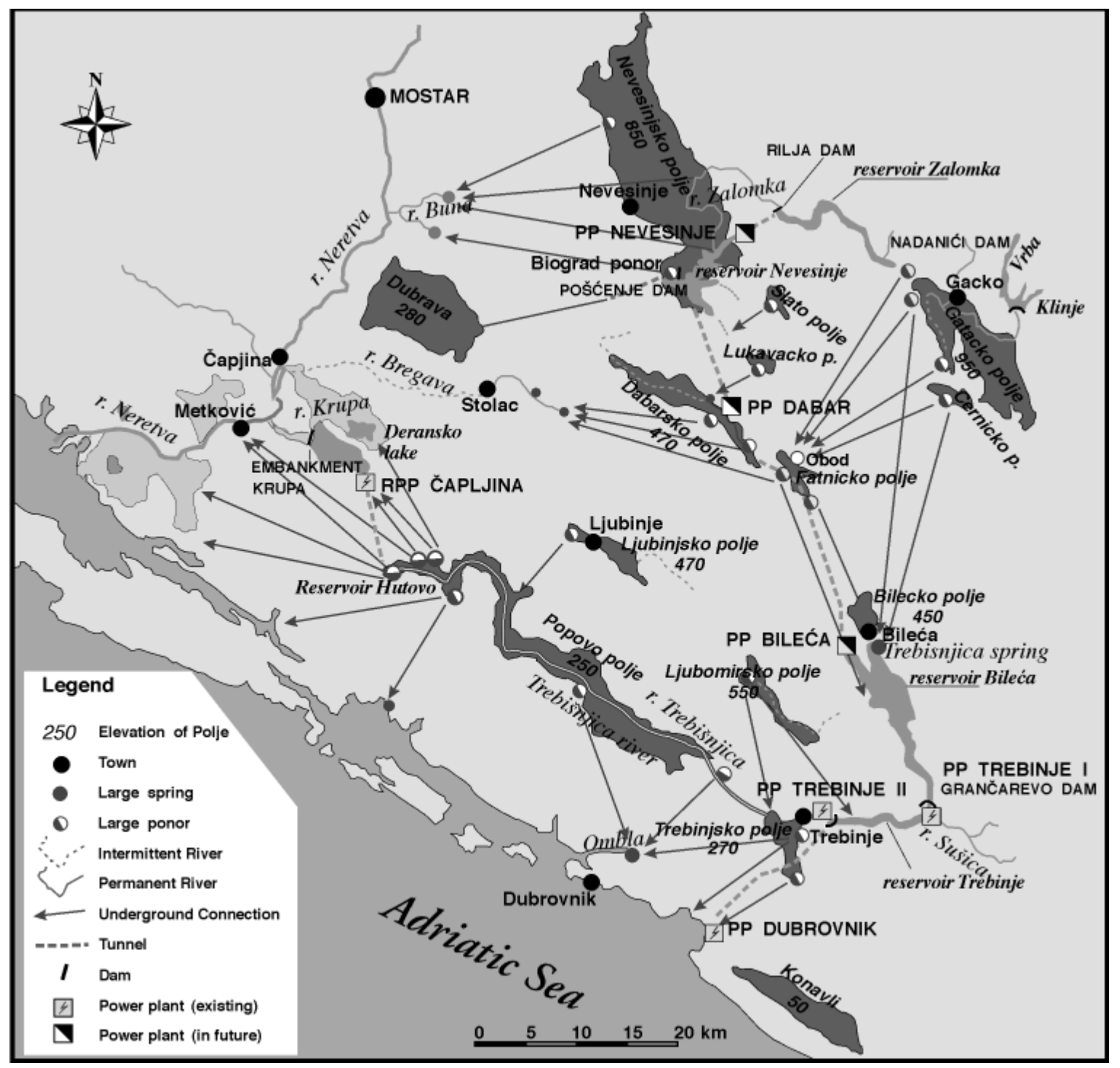

Figure 1 Hydrosystem Trebisnjica, layout.

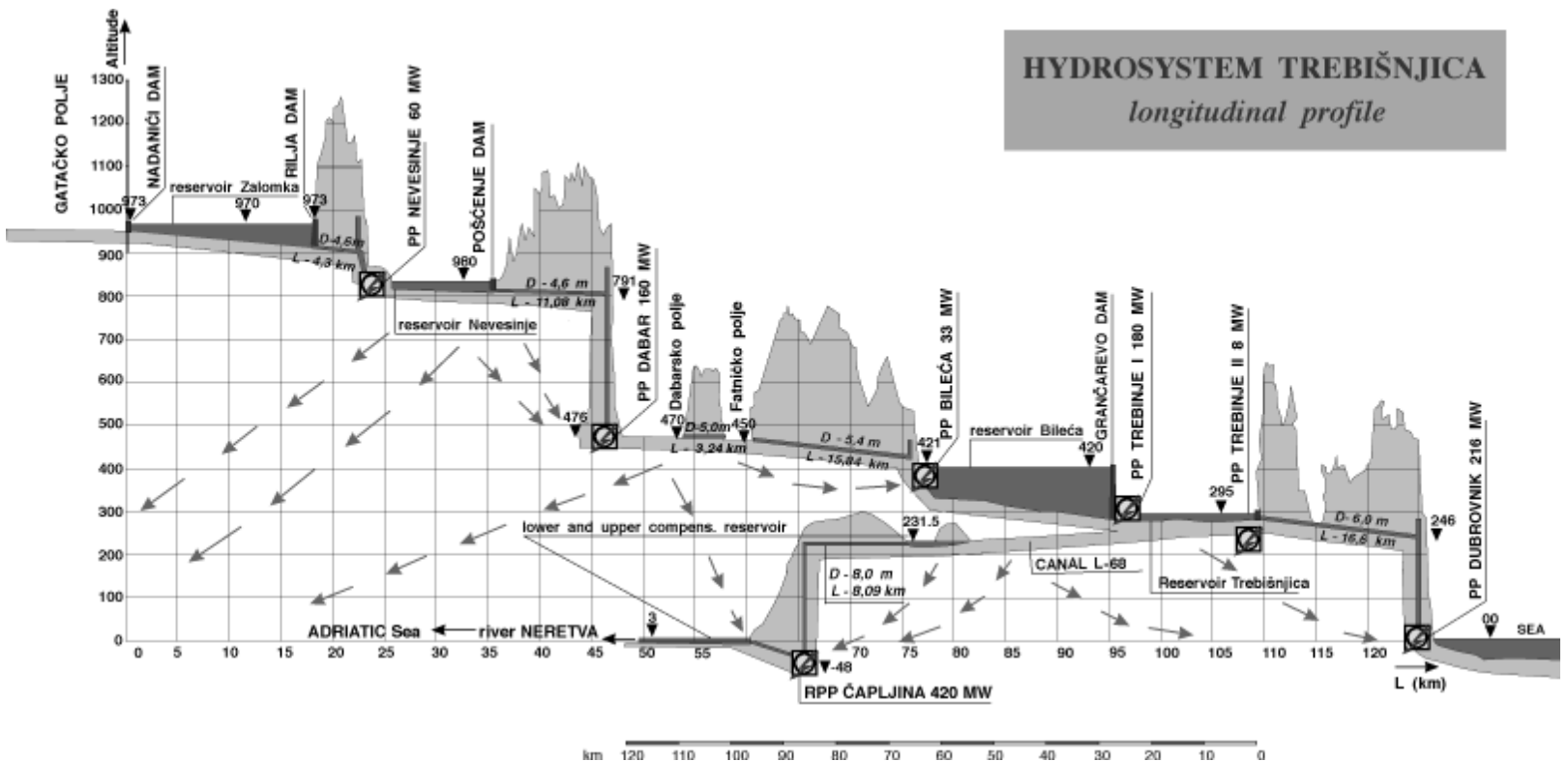

Figure 2 Hydrosystem Trebisnjica, longitudinal profile. Arrows indicate general direction of underground flows. 
During construction of the first phase of this project, karst aquifers were starved of about 4 billion cubic metres of water annually as a result of re-routing through a great number of tunnels and paved channels for power production and drainage of many swallow holes (ponors). Many smaller and some large ponors no longer function effectively as concentrated recharge sources (Biograd-110 $\mathrm{m}^{3} / \mathrm{s}$, Doljasnica- $55 \mathrm{~m}^{3} / \mathrm{s}$, Pasmica $-25 \mathrm{~m}^{3} / \mathrm{s}$, Crnulja-10 $\mathrm{m}^{3} / \mathrm{s}$, Provalija $-10 \mathrm{~m}^{3} / \mathrm{s}$ ). Upon completion of Trebisnjica Hydrosystem, the total deficit of aquifer recharge is expected to be around 6 billion cubic metres (P. Milanovic, 1990).

The hydropower system of "Gornja Zeta" (Yugoslavia) required construction of a large cylindrical dam to prevent focused water losses through the ponor Slivlje (swallowing capacity 120 $\mathrm{m}^{3} / \mathrm{s}$, Figure 3). A similar structure was constructed around the large estavelle Opacica, at the rim of the storage reservoir. Smaller swallow holes are usually plugged by grouting, for instance, Krupac Ponor (swallowing capacity of $4 \mathrm{~m}^{3} / \mathrm{s}$ ). Because of these structures, millions of cubic metres of water now flows through the pipeline to the power plant rather than recharging part of karst aquifer of Niksicko Polje.

With construction of reservoir (Busko Blato, Bosnia) for the power plant Orlovac (Croatia) a few single ponors (swallowing capacity between 1.0 and $20 \mathrm{~m}^{3} / \mathrm{s}$ ) were isolated by construction of two rock-filled dams and five grout curtains, as well as blocking of specific karst channels by the concrete plugs (Nikolic and Nonveiller, 1976). The consequence here has been starvation of karst aquifers between Busko Blato and sea level.

\section{Influence on karst springs}

Water stored at higher reservoir elevations influences the water regime in springs at lower elevations. A concern for all hydropower projects is that springs at lower erosion levels may cease to function. The most frequent change is a reduction of annual discharges. However, the base flow discharges of many springs were also increased. Leakage from reservoirs, tunnels and lined river beds at higher elevations provokes increased discharge at lower springs. Some intermittent springs have also become permanent.

Changes in the flow regime in downstream springs and in particular increase in minimum discharges often create conflicts between the owners of the reservoir and the users of the spring. If, as a result of building reservoir, minimum spring discharge is increased, the spring users usually react to increasing water demand by building new or increasing capacities of existing tapping structures (e.g., for new industries, hotels, farms, plantations).

Conflict issues also occur when a reservoir or other structures (tunnel or channel) have to be emptied for overhaul purposes. The natural flow regime is restored during these intervals, and the capacity of the spring zone decreased and re-established to its original levels. As a consequence, there is a deficiency of water for all consumers. Overhauls usually take place in the summer months when demands and requirements for power are minimal and water levels in the reservoir are lower. However, this period coincides with the time of highest water consumption and intensive irrigation by spring users. Resolving water resource conflict issues between power plant owners and spring consumers requires common sense and an understanding of the karst systems involved. This situation is especially delicate if the reservoir and springs are in regions of different political entities.

A good example of this situation is the Trebisnjica Hydrosystem project, where an inventory of springs and monitoring program began 8 years before the project was operational. A total of 120 springs that could potentially be affected by construction were catalogued along a $100 \mathrm{~km}$ length of the Adriatic Sea coast, and along 50 $\mathrm{km}$ of the Neretva River. Data collected included position, elevation, discharge and use of springs. Initially, 46 springs were selected for permanent monitoring and equipped with water gauge stations. After two years, the number of monitored springs was reduced to 26 . At this time, a few tens of tracer tests were completed. In the case where a spring's minimal discharge decreases, Trebisnjica Hydrosystem has an obligation to compensate for the water losses. The basic values were agreed to be those observed and measured during the driest hydrological period (i.e., during minimal spring discharge).

Monitoring of data before and after construction revealed that there was no influence on the minimal spring discharge. Moreover, the minimal spring discharge of some springs increased. However, the annual average discharge at some of the large springs considerably decreased. For example, average yearly discharge of Ombla Spring (Croatia) under natural regime was $\mathrm{Q}_{\mathrm{av}}=33.8 \mathrm{~m}^{3} / \mathrm{s}$ but after construction of Hydrosystem Trebisnjica, which influenced a part of Ombla catchment, the discharge was reduced to $\mathrm{Q}_{\mathrm{av}}=24.4$ $\mathrm{m}^{3} / \mathrm{s}$. There was no change in the minimal spring discharge.

A different impact can be expected in the case of intensive groundwater extraction from high elevation karst springs and underground flow routes. Uncontrolled pumping from karst channels in small catchment areas can result in a decrease in spring discharge at lower elevations. "Obviously, to extract the subsurface streams in the upper course will closely influence the discharge of karst springs and flow quantity in down course channels within the same catchment area or same hydrodynamic condition" (Lu Yaoru, 1986). This negative impact is most likely to occur during dry hydrological periods (i.e., during minimum spring discharge).

Figure 3 Photo of cylindrical dam around ponor Slivlje in the dry period. 


\section{Impact of large structures on upstream aquifer regime and floods}

One of the major characteristics of the closed polje is the exclusive underground outflow of all surface water. This can cause temporary flooding of karst poljes. Poljes become flooded at the moment the sink or recharge capacity of the ponor is exceeded by the inflow quantity of water. Settlements and infrastructure in temporarily flooded poljes are located with the respect of ponor swallowing capacity (i.e. with respect to the historically highest flood).

Complete dewatering of karst poljes can only be achieved by tunnel driving or construction of reservoirs. In the past, dewatering of temporarily flooded poljes was solved exclusively by tunnel driving. Numerous settlements have been protected against flooding, and intensive agriculture is now possible in previously inundated areas.

However, settlements may still be threatened by flooding if high-magnitude hydrometeorological events (e.g., snow melting simultaneously with heavy rain showers) coincide with favourable hydrogeological conditions. An example is a catastrophic flood in the polje of Cetinje (Yugoslavia) which occurred because the transmissivity of the epikarst system was far above the deep base flow capacity (i.e., the transitive capacity of the main karst conduit was insufficient). The resulting flood was the highest in the 500-year history of this small town (B. Mijatovic, 1987).

One of the multi-purpose roles of dams in karst regions is to protect poljes from flooding. In practice, however, reservoirs may flood caves, surface depressions and valleys with arable land. These potential impacts are often reason enough to abandon a new project. For example, construction of the Lower Gordon dam in southwest Tasmania would have flooded a large karst area containing caves of great archaeological importance. The project was abandoned for legal and environmental reasons in 1983 (Kiernan, K. 1988).

Flooding in upstream poljes can be an unfavourable consequence of underground storage. In Jijiao, Xinchen County (Guangxi, China) during a recent rainy season, arable land in depressions was flooded and 240 people were evacuated as a result of underground storage (Yuan Daoxian, 1983).

Submergence of spring zones by artificial reservoirs also influences the water balance of spring zones in adjacent karst aquifers and flood regime in upper regions. For example, with the construction of a $123 \mathrm{~m}$-high dam, the large and permanent Trebisnjica Spring was flooded by water to a depth of about $75 \mathrm{~m}$. The annual average discharge of this zone is $80 \mathrm{~m}^{3} / \mathrm{s}$, velocity of underground flows varies between 0.9 to $14 \mathrm{~cm} / \mathrm{s}$ and water table fluctuations are very rapid with amplitude up to $120 \mathrm{~m}$.

The analysis has shown that the flooding of springs has some influence on the hydrogeological conditions of the upstream polje and the surface in the immediate tributary area. The submergence of spring zone affects the dynamics of the emptying of the karst aquifer. The high water levels of the storage reservoir decrease the hydraulic gradient so that the flow velocities are smaller in relation to natural conditions. Decline of the water table under natural conditions is represented in Figure 4, by the recession part of hydrograph (1). A great number of observations show that $150 \mathrm{~h}$ was needed to lower the water table. Since the springs of the Trebisnjica River were inundated the recession part of hydrograph (2) has had a flatter slope. To lower the water table now to the same level, about $300 \mathrm{~h}$ are needed. This means the emptying of this part of the aquifer is retarded in relation to the former natural regime.

This change of discharge regime has affected and prolonged the duration of flooding in upper polje (Fatnicko Polje), but has not affected flood height or the total hydrological balance of the polje.

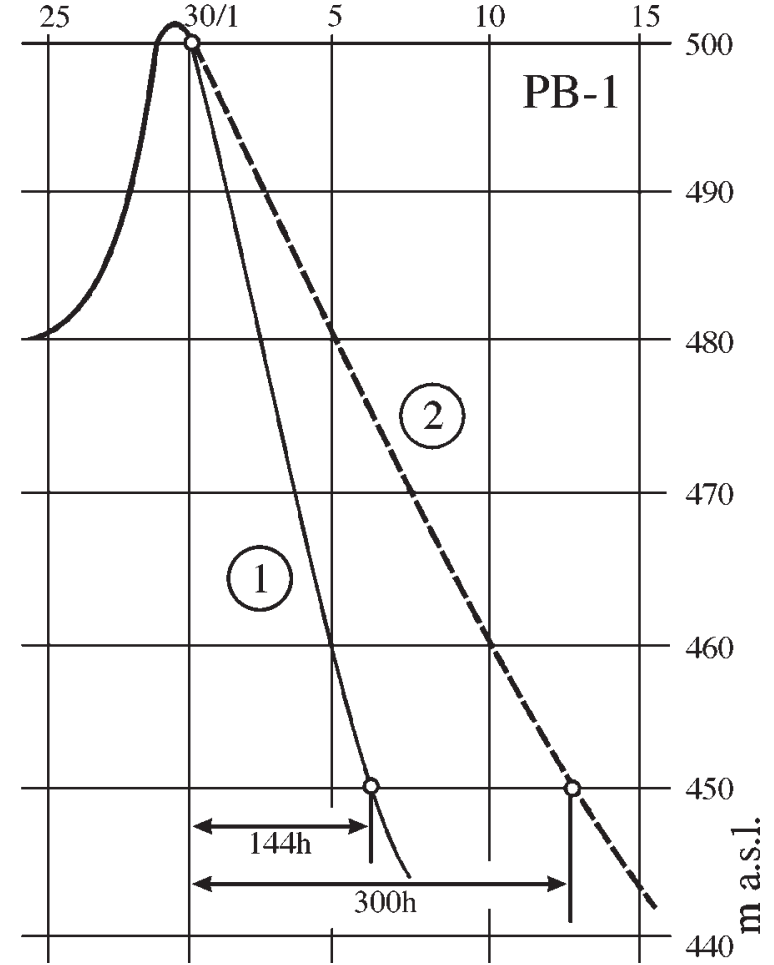

Figure 4 Water table recession curves recorded in borehole PB-1. 1. Recession curve under natural conditions; 2. Recession curve after reservoir filling.

\section{Grout curtain influence}

The main purpose of grout curtains is to change the hydrogeological characteristics of the rock mass. High non-homogeneity in permeability of karst terrains makes them most difficult targets for grouting. Particular problems posed during the grouting are the zones of concentrated underground flow. By plugging concentrated underground flow routes, the grout curtains essentially change the filtration conditions and provoke a disorder to which medium reaction is sometimes unpredictable. Long and deep unpervious or semipervious grout curtains sometimes drastically influence the local aquifer regime.

To prevent salt-water contamination of the Tabacina Spring intake structure (Kotor Bay, Yugoslavia), a $220 \mathrm{~m}$ long by $45 \mathrm{~m}$ deep grout curtain was constructed to connect with an underlying impervious flysch complex. After a few years of satisfactory operation, salt-water intrusions again started to contaminate the spring and continuous discharge began at the intermittent Orahovica Spring some 7 $\mathrm{km}$ from the grout curtain. Despite rigorous field investigations and analyses, unexpected hydrological and hydrogeological situations will always arise.

\section{Groundwater protection}

Groundwater protection in karst regions is one of the crucial problems for regional planning and development. In the past few decades humaninduced impacts on karst groundwater have been the focus of hundreds of articles and many interdisciplinary conferences and symposia.

The karst aquifer is very sensitive and should be under strict sanitary protection. The criteria for determining zones of sanitary protection in karst are essentially different from criteria for a nonkarst terrain. One of the most important differences between the karst aquifer and aquifers in intergranular or low permeable rocks is a considerably shorter contact period of the contaminant with rock matrix due to the rapid circulation through karst conduits $(0.5-50$ 
$\mathrm{cm} / \mathrm{s}$ ). The lack of soil deposits at surface (with filtering function) and concentrated infiltration through large ponors enhance rapid transport of contaminant into the aquifer. The contaminated water waves quickly spread through the karst aquifer, i.e., the time available for the autopurification process is very short. There is no enough time for degradation of organic materials and elimination of bacteria. The weak autopurification ability of the karst underground only contributes to the intensity of long-lasting contamination.

Extremely large surface zone permeability and intensive precipitation "guarantee" fast contamination of karst aquifers. The higher the elevation of the contaminated aquifer, the greater is the size of the area endangered.

Turbidity of water in karst springs is relatively common after sudden heavy precipitation. In some cases, turbidity levels are so high that for a short time, water becomes non-potable. Turbidity begins with the arrival of water waves, peaking at the same time as peak discharge, and decreases as flow starts to wane. Many analyses have shown that the period of turbidity represents the period of increased water pollution with bacteria.

\section{Waste disposal locations and sewage treatment lagoons}

Waste disposal in karst terrains represents a serious and complex problem. Especially if there are those who think that every sinkhole and shaft can serve as a suitable location for waste disposal. Problems arise because it is practically impossible to find a location that would be safe for the disposal of wastes without serious protective measures. There are many instances of trash-filled shafts and ponors in the catchment areas of very important tapped springs that are used without any protection. Examples include large shaft as municipal waste disposal site; large swallow holes (ponors) on farms used as disposal sites for dead chickens and sheep.

In one case, sewage from a settlement of approximately 6000 inhabitants in the Dinaric karst region discharges into a ponor without treatment. Water from this ponor flows directly toward a large spring with a discharge capacity ranging from 2 to $150 \mathrm{~m}^{3} / \mathrm{s}$. Contaminated water travels a (straight) distance of $16.5 \mathrm{~km}$ in only 75 hours: too short a time for any self-purification process to occur, and consequently spring water is polluted.

Failures of sewage treatment lagoons are extremely dangerous. The collapse that occurred at the West Plains, Minnesota in 1978 contaminated local aquifer and resulted in 800 cases of flu-like illnesses among people who drank contaminated groundwater (Alexander E.C. \& Book P.R., 1984).

Failure of ash and slag deposits from thermal power plants and mine tailings can also have catastrophic implications for springs and settlements.

\section{Induced seismicity}

The first registered example of induced seismicity was related to the Hoover Dam, USA during 1930s. Subsequently, a number of cases related to the induced seismicity caused by large dams and reservoirs have been documented in different regions of the world, some with serious human and material losses (Xinfengjiang - China, $\mathrm{M}=6.1$; Kremasta - Greece, $M=6.3$; Koyna - India, $M=6.5$ ).

Induced seismicity was triggered during the first filling and operation of large dams in the karst regions of Grancarevo, Herzegovina $(M=4.5)$ and Piva/Mratinje, Yugoslavia $(M=4.1)$. It is interesting to note that analyses of certain earthquakes indicate the role of karst nature in genesis of some induced seismic shocks. Those analyses indicate possible explosions of the compressed air during an abrupt reservoir impounding and simultaneous abrupt rising of the water table in the surrounding karst aquifer. Pressure of the air trapped in the karst channels and siphons significantly increases.
Trapped "air pillows" escape creating strong explosions that, at the surface, are felt by the inhabitants and recorded by the nearby seismological stations. The environmental impact of this process is generally local, but could be harmful.

The same phenomenon, but of smaller intensity, occurs under natural conditions in the region of the large intermittent karst spring Obod (Herzegovina). The inhabitants of this region have noticed that 15 to $30 \mathrm{~h}$ before the spring becomes active, the ground shakes with periodic strong seismic shocks (P. Milanovic, 2000). Discharge of spring varies between 0 and $60 \mathrm{~m}^{3} / \mathrm{s}$ (Figure 5).

To prevent groundwater outflow, the spring outlet was closed with a massive concrete plug $(10 \mathrm{~m}$ high and an average of $3.5 \mathrm{~m}$ wide). After plugging, an extremely high rainfall (more than $200 \mathrm{~mm} /$ 24 hours) caused the water pressure in the karst channels to increase rapidly up to 10.6 bars. Tens of new springs with a total discharge of about $11 \mathrm{~m}^{3} / \mathrm{s}$ formed at hill slopes 80 to $100 \mathrm{~m}$ above the plug level. Springs also appeared inside some houses of the village.

Extremely rapid filling of the aeration zone produced an explosion of air under pressure which was trapped in the conduit system, and triggered strong but local earth shaking. As a result, a road on the hillside above the plugged spring started sliding and many houses were damaged at a distance up to 250-300 m above the Obod Spring. Since the impact on the local environment was too dangerous and risky, the concrete plug was blasted.

Because of the above-described events, a 1-component seismic station (Z-component) was temporarily installed above this spring. Subsequently, it registered vibrations and shocks similar to those reported earlier.

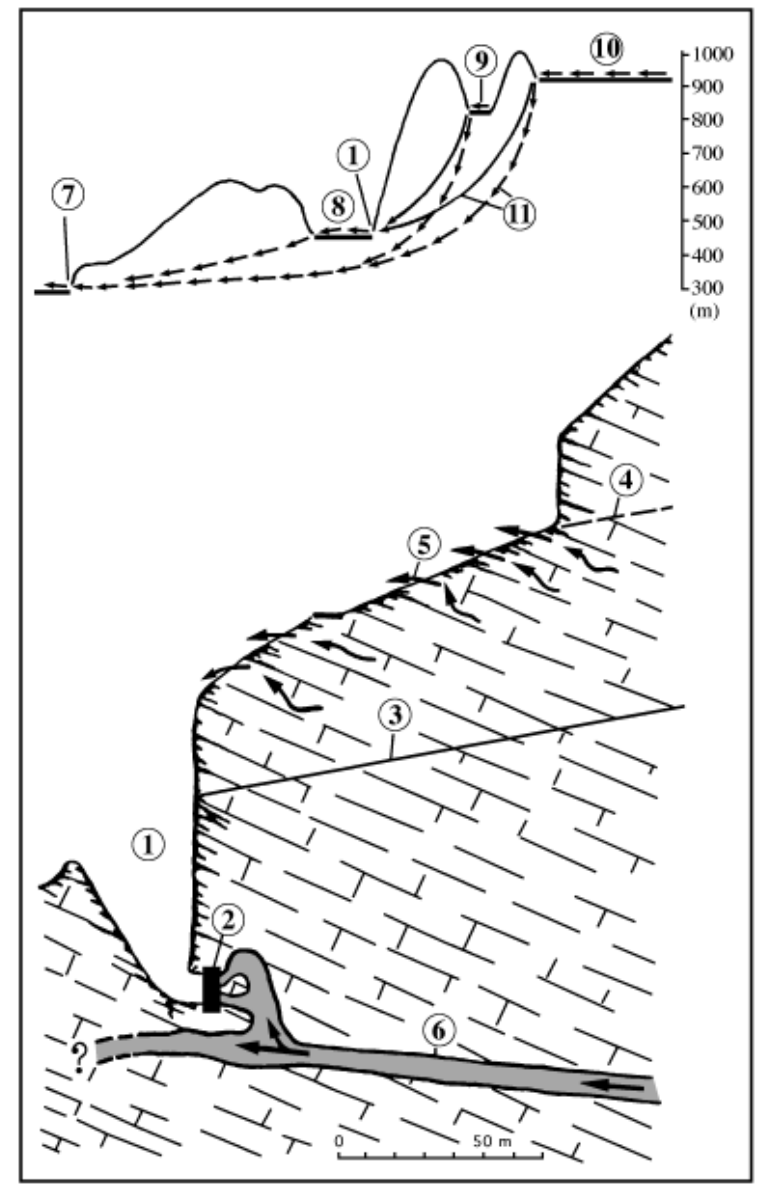

Figure 5 Experimental plugging of "Obod" estavelle.

1. "Obod" estavelle; 2. Reinforced concrete plug; 3. Piezometric line, in natural conditions; 4. Piezometric line after plugging; 5. Discharge points after plugging; 6. Karst channel; 7. Trebisnjica spring; 8. Fatnica polje; 9. Cernica polje; 10. Gacko polje; 11. Underground connections. 
Similar events have been observed elsewhere in the Dinaric karst. Local seismic activities are always registered during the rainy season when there is intensive filling of karst aquifer (karst channels) and rapidly rising groundwater levels.

\section{Induced subsidence}

Subsidence events are spatially independent random occurrences and have been identified as sources of major potential problems. Subsidence has caused considerable damage in reservoir bottoms, in urban areas, at industrial sites and near communication lines. The catastrophic nature of subsidence development is unpredictable and practically instantaneous, therefore very harmful.

Subsidence is common when karstified rocks are covered with unconsolidated sediments. Overburden thickness in subsidenceprone areas varies from a few metres to greater than $50 \mathrm{~m}$. Subsidence occurs under the influence of water (groundwater, flood water and pore water) as erosion and piping action breaks down the support of poorly consolidated sediments. In rare cases, water pressurizing air in the aeration zone has triggered blow-outs through the overlying sediments.

Subsidence triggered by groundwater pumping, mining, dam construction, tunneling and drainage is a problem in many karst regions of the world. In the United States alone, more than $25,000 \mathrm{~km}^{2}$ have been directly affected by subsidence.

According to S.L. Hua (1987), subsidence due to groundwater pumping was reported from 25 areas in China during the period 1974 to 1986 . In one extreme case, 600 subsidence events were recorded in an area of 5 $\mathrm{km}^{2}$.

In the period 1999 to 2000,34 catastrophic subsidence events occurred as a result of human activities including mining, groundwater pumping and waste storage. Of these, 21 formed in a period of less than four days. As a result, 127 houses were destroyed and 1215 residents were left homeless (Mingtang L. et al., 2000).

The maximum reported subsidence density in China is greater than 500 per $0.1 \mathrm{~km}^{2}$. The largest subsidence event occurred in Sichuan Province-a structure $400 \mathrm{~m}$ in diameter and $176 \mathrm{~m}$ in depth (Shouyue Z., 1984).

Recent subsidence in the Karapinar area (Turkey, 2000, unpublished) occurred in a 60 to $70 \mathrm{~m}$ thick deposit of marly clay. In spite of the thick overburden, a few shaft-like collapse structures (20 to $25 \mathrm{~m}$ in diameter, and 60 to $70 \mathrm{~m}$ in depth) formed instantaneously.

Induced subsidence developed as a consequence of urbanization, mining, reservoir construction and ground water extraction dramatically increased in the second part of the 20th century. According to LaMoreaux \& Newton (1986), thousands have been formed in the USA since 1950 . More than 80 percent of the identified events are a consequence of uncontrolled exploitation of underground water. "In 1991, the National Research Council estimated that annual costs in the USA from flooding and structural damage caused by land subsidence exceeded \$ 125 million" (USGS, Circular, 1182). Indirect costs are many times higher.

The magnitude of subsidence caused or accelerated by human activities can be catastrophic. These occurrences are well documented in the literature, especially in publications of Chinese and American geologists. Intensive pumping of karst aquifer in Florida recently provoked formation of 650 subsidence features over a relatively short time. According to Brink (1984) after 25 years of pumping in a gold mine district in South Africa, 38 people have lost their lives in collapse, and damage to the buildings and structures was enormously high. In one event, 29 men lost their lives when a threestory building collapsed.

Subsidence development is also a very common process which endangers safety and integrity of dams and reservoirs. Subsidence induced by extensive water level fluctuation in man-made reservoirs has resulted in much leakage from certain reservoirs (Mavrovo Reservoir - FYUR Macedonia, $7 \mathrm{~m}^{3} / \mathrm{s}$; Vrtac - Niksicko polje, Yugoslavia, $2 \mathrm{~m}^{3} / \mathrm{s}$; Keban Dam - Turkey, $26 \mathrm{~m}^{3} / \mathrm{s}$; Hutovo Reservoir - Herzegovina, Yugoslavia, 3 m³/s; Perdika Reservoir - Greece; May Reservoir - Turkey; Kamskaya Dam - Russia).

The form of subsidence structures varies. In some cases, subsidence develops between two parallel cracks (Figure 6, a); as large

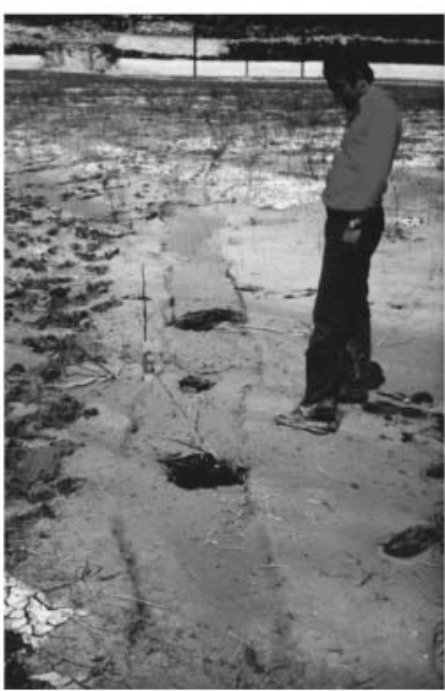

$a$

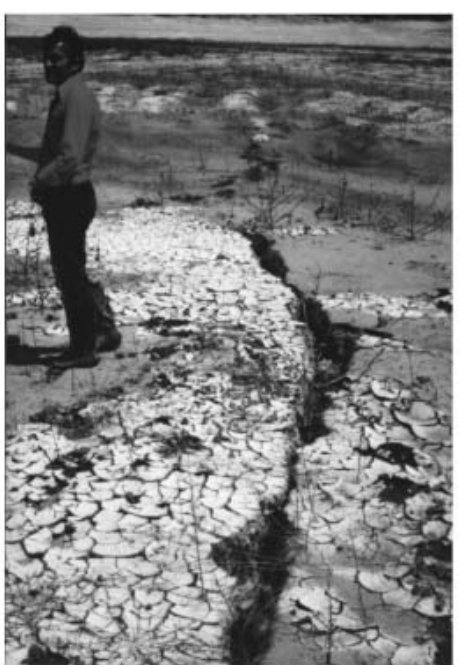

c

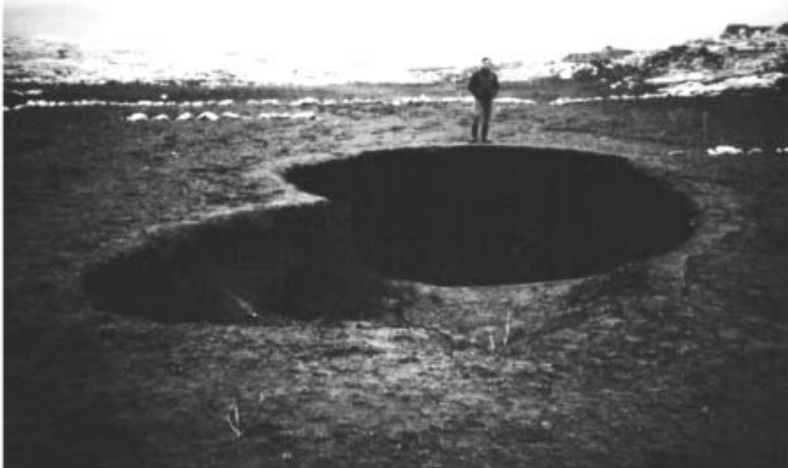

$b$

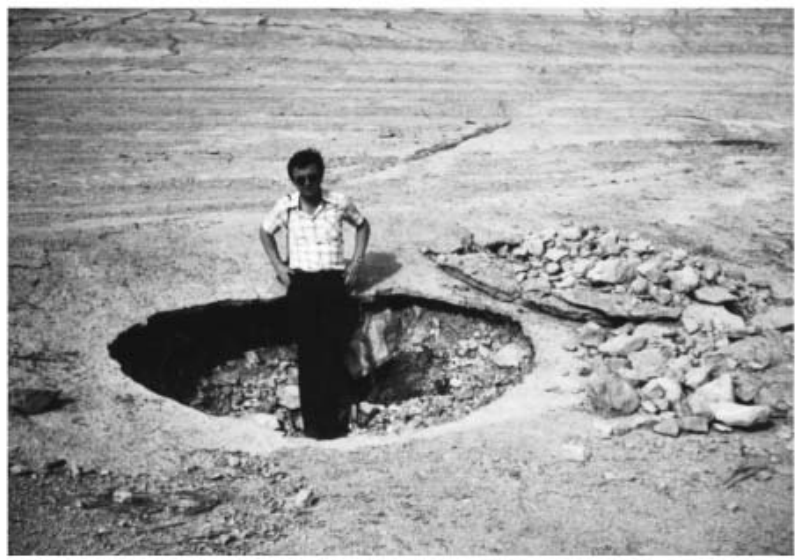

$d$
Figure 6 Different types of induced subsidence at bottom of man-made reservoirs. 
open funnels (b); as long and wide open crack (c); or circular opening in shotcrete lining (d) as a consequence of strong uplift during groundwater eruption.

In spite of several different geotechnical measures intended to improve watertightness of the bottom in the Vrtac retention basin, more than 100 new collapse ponors (swallow holes) were formed. In some cases, collapse provoked considerable environmental impact. For instance, subsidence in the Mavrovo reservoir resulted in heavy damage of local roads and surrounding houses.

Defects during the underground excavation and operation in karst can provoke undesirable effects at the surface, especially in the case of thin overburden. Defects during tunnel operation are very common in karst environments. This is illustrated by the following example. Water leakage from a head race tunnel tube had eroded and washed away nonconsolidated cave deposits in the section where the tunnel intersected a large filled cavern. Percolation through the lining caused intensive erosion and transport of great volumes of clayey-sandy cave deposits toward deeper channel sections over time, an empty space around the tunnel tube developed and subsidence formed at the surface (Figure 7).

Poor management of underground reservoirs can also trigger subsidence at the surface. Inadequate operation of the intake pipes and bottom outlets induced collapse failure above the underground storage space of Jedres Spring (Herzegovina). The karst channel of the spring was plugged

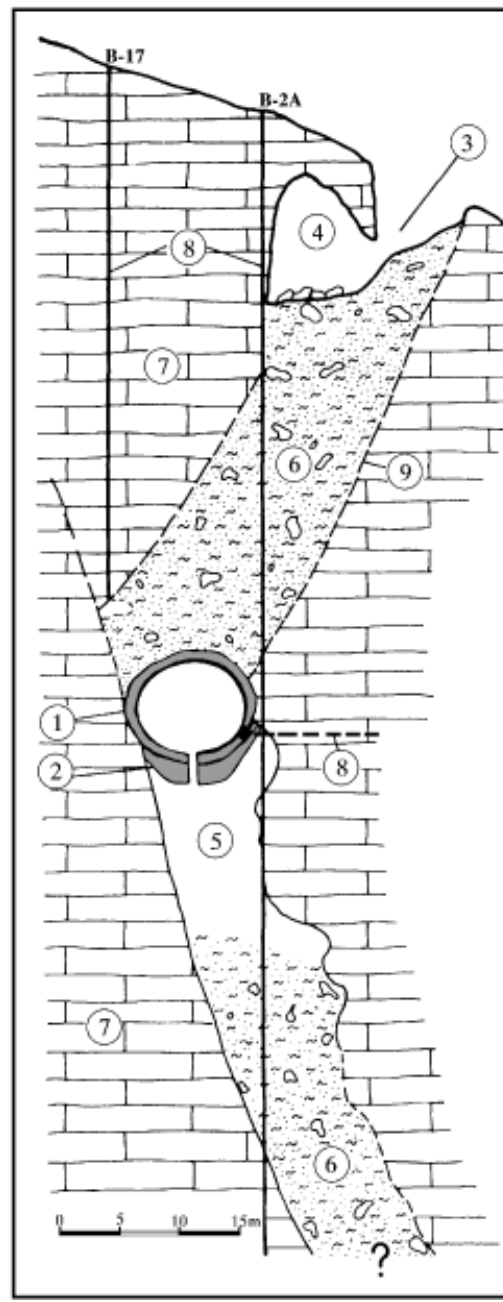

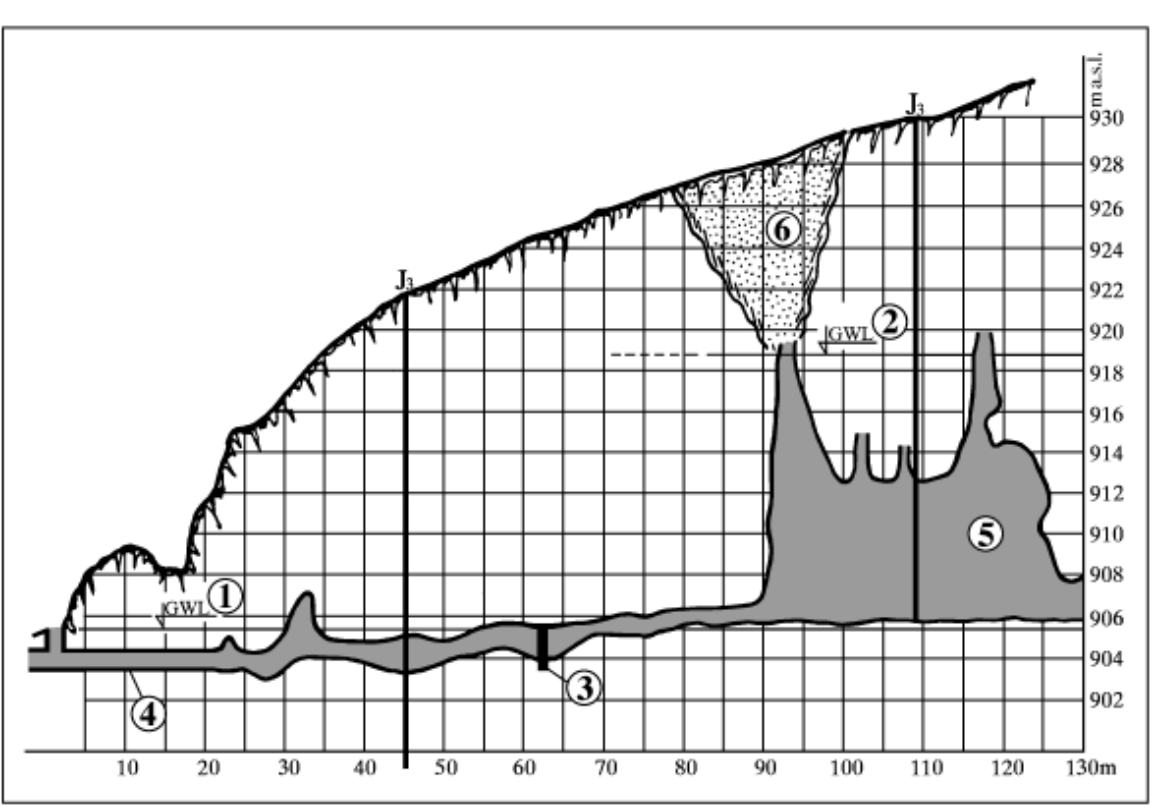

Figure 8 Cross section along the part of underground storage space.

1. Max. water table under the natural conditions; 2. Max. permitted storage level; 3. Concrete plug; 4. Outlet part of the karst channel; 5. Storage space; 6. Collapsed part of the overburden.
oncte

by concrete to provide underground storage for water supply. The bottom outlet and all valves in the plug structure were closed at the time of heavy precipitation. An abrupt increase of water pressure behind the plug provoked a collapse of the surface above the underground reservoir (Figure 8).

Human activities can also play a special role in inducing or enhancing karst processes in evaporitic rocks, and the results can be catastrophic (K.S. Johnson, 1997). Induced collapses in salt deposits are mostly associated with solution-mining and petroleum extraction. The size of (subsidence) collapse structures varies between $10-100 \mathrm{~m}$ in diameter and $10-600 \mathrm{~m}$ in depth.

\section{Problem of caverns at dam sites}

During dam construction unique problems are posed by the presence of caverns. In extreme cases, caverns may be large and extensive enough to thwart geotechnical solutions. The most frequent technical difficulties are water leakage at dam sites and from reservoirs, and break-in of water and mud during tunnel and other underground excavations.

Practical solutions of this sort of problem are extremely complex and require much time and sufficient financial resources. Reservoirs in karst areas may fail to fill despite an extensive investigation program and sealing treatment. Every problem is unique and past responses are never repeated.

A number of examples illustrate the magnitude of this problem. Large caverns have been discovered at many dam sites and reservoirs in karst regions, for instance: Keban (Turkey), Lar (Iran), Camarasa (Spain), Sklope (Croatia), Canelles (Spain), El Cajon (Honduras), Great Falls (USA), Khao Laem (Thailand), Marun (Iran), Wujiangdu (China), and Salman Farsi (Iran).

One of the most karstified dam sites is Salman Farsi, Iran. Here, a few tens of caverns have been discovered along the grout curtain route (Figure 9). The volume of some caverns exceeds $20,000 \mathrm{~m}^{3}$.

One of the largest caverns was discovered at Keban dam site (Turkey), where reservoir losses amounted to $26 \mathrm{~m}^{3} / \mathrm{s}$. Drainage of the reservoir was reduced after a $2.5 \mathrm{~m}$ diameter shaft and thirteen $0.4 \mathrm{~m}$ diameter boreholes were drilled into the cavern and plugged with $606,000 \mathrm{~m}^{3}$ of limestone blocks, gravel, sand and clay. 


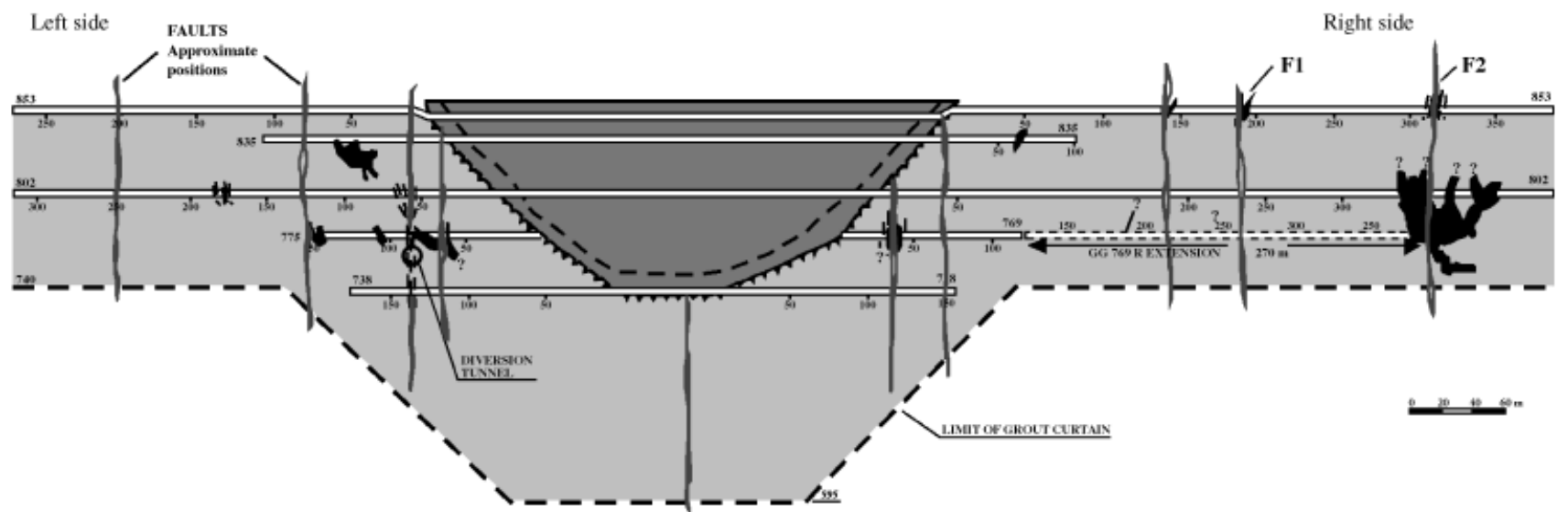

Figure 9 Salman Farsi Dam site (Iran). Cross-section along the grout curtain with approximate position of caverns (J.V. Stucky-Electrowat, 2000).

\section{Underground fauna endangering}

In contrast to nonkarst terrains, karst underground is very rich with various fauna. In one cave (Vjetrenica, Herzegovina), more than 55 different underground species have been recorded. Seventeen of them are declared as endemic species. In a survey of 82 caves in the USA, 1042 of the 1475 species are known from fewer than five sites, and 316 species are known from a single cave (J. Roth, 1999).

Changes in the underground and surface water regimes have a very distinct negative effect on the fauna of subterranean karst. Often as a result of dam and reservoir construction in karst, a large volume of voids in the aeration zone is flooded. This changes cave habitat for a number of rare species that cannot survive the flooding. Dam construction has resulted in flooding of caves inhabited by many endemic species, for example: Normany Dam (Tennessee, US); Melond Dam (California, US); and Scrivener Dam (Australia). Aquatic endemic species are also threatened during abrupt reservoir fluctuation, especially during rapid and total drawdown for overhaul purposes.

Dewatering of temporary flooded poljes is catastrophic for aquatic organisms that inhabit karst siphons during dry periods and ephemeral lakes during flood seasons. An example is the Gaovica fish (Paraphoxinus ghetaldi) which spends dry (summer) months in numerous siphonic lakes and pools of the underground karst. During periods when the polje floods, the fish leaves the underground through karst channels and openings of estavelles. For the duration of inundation, the fish lives in the intermittent lakes of the karst poljes. With construction of Trebisnjica Hydrosystem, the Popovo Polje was prevented from flooding and the river bed lined with concrete. As a result, the Gaovica fish has lost connections with the surface in most locations and is now threatened with extinction. Fishing at the openings of estavelles, for centuries an important tradition and food source for inhabitants of Popovo Polje, has also completely vanished.

A well-known cave-dwelling aquatic endemic species of the Dinaric karst is Proteus anguinus, the 'human fish'. In the Popovo polje region, this fish was found in 37 localities. Hydrotechnical constructions and urbanization have seriously endangered this endemic species. Within the Trebinje townsite alone, a number of localities with Proteus anguinus have been destroyed by building and road construction (S. Cuckovic, 1978).

Also with the change in the natural hydrological and hydrogeological characteristics of Popovo Polje, the large concentration of endemic worm-Mariphugia cavatica and mollusc Kongeria-are seriously endangered. Both species exist under normal conditions in siphonal sections of two large ponors with swallowing capacities of $10 \mathrm{~m}^{3} / \mathrm{s}$ and $60 \mathrm{~m}^{3} / \mathrm{s}$. The survival of both species is threatened now that inundation of the polje is controlled and the Trebisnjica River bed lined with shotcrete obstructing water flow into the ponors.
The liberation of the Popovo Polje from inundation has also decreased the activity time and discharge of a series of intermittent and submarine springs along the Adriatic coast. The operation of a commercial oyster and mollusc farm has been threatened because of reduced freshwater outflow through the submarine springs. A long term investigation has been undertaken to study the effects of hydrological and hydrogeological changes on living conditions in the farm area.

\section{Summary}

Many karst regions of the world face unique technical, managerial and political challenges as demands on water resources increase.

Reclamation projects, construction of large dams and reservoirs, deep underground excavations and complex foundation structures have profound impacts on karst function, in addition to regional ecological, infrastructure, social and political systems.

The important issue in karst regions for the future is how to keep the balance between the necessity for development and preservation of unpredictable and complex hydrogeological systems.

\section{Acknowledgement}

I would like to express my gratitude to Dr David Huntley with the Shearwater Mapping Ltd, of the British Columbia Open University, Canada, who read through the paper and suggested many language corrections which have improved its clarity.

\section{References}

Alexander, E.C., Book P.R., 1984. Altura Minnesota lagoon collapses, in B.F. Beck, ed., Sinkholes: their geology, engineering \& environmental impact. A.A. Balkema/Rotterdam/Boston.

Brink, A.B.A., 1984. A brief review of the South African sinkhole problem. in B.F. Beck, ed., Sinkholes: their geology, engineering \& environmental impact. A.A. Balkema/Rotterdam/Boston.

Cuckovic S. 1978. The question of the survival of well-known endemic Proteus Anguinus in the part of the Trebisnjica power system. Conference on environmental effects of storage reservoirs. Yugoslav Committee for Large Dams. Trebinje.

Galloway, D., Jones, D.R., Ingebritsen, S.E., 1999. Land subsidence in the United States. U.S. Geological Survey, Circular 1182.

Hua, S.L., 1987. Pumping subsidence of surface in some karst areas of China Symposium on human influence on karst, Postojna, Yugoslavia

Johnson, K.S. 1997. Evaporate karst in the United States. Carbonates and Evaporates, Vol. 1. 31, No.5.

Kiernan K. 1988. Human impacts and management responses in the karsts of Tasmania. Proceedings of the International Geographical Union, Study Group Man's Impact on Karst. Sydney. 
LaMoreaux P.E., Newton J.G., 1986. Catastrophic subsidences: An environmental hazard, Shelby County, Alabama. Environmental Geology Water Sci. $8(1 / 2)$.

Lu Yaoru, 1986. Some problems of subsurface reservoirs constructed in karst regions of China. Institute of Hydrogeology and Engineering Geology, Ministry of Geology and Mineral Resources, P.R. China.

Mijatovic, B., 1987. Catastrophic flood in the polje of Cetinje in February 1986, a typical example of the environmental impact of karst, in B.F Back \& W.L. Wilson, eds., Karst Hydrogeology: Engineering and Environmental Applications. A.A. Balkema/Rotterdam/Boston.

Milanovic, P., 1990. Influence of construction on hydrogeological and environmental conditions in the karst region, Eastern Herzegovina, Yugoslavia. Environmental Geology Water Sci., Vol. 15, No.1. SpringerVerlag New York Inc.

Milanovic, P., 2000. Geological engineering in karst. Zebra Publishing Co., Belgrade, Yugoslavia.

Mingtang, L., Jiang, X., Liyu, 2000. Review of collapses in China during 1999-2000, in Xie Yunqiu \& Yao Changhong, eds., Newsletter, Project 448, Guilin, China.

Nikolic, R., Nonveiller, E., 1976. Grout curtains of storage "Busko Jezero". Working papers of the First Yugoslav Symposium for the Soil Consolidation, Zagreb, Croatia.

Roth, J., 1999. Threats to endemic cave species. American Caves.

Shouyue, Z., 1984. Karst subsidence in China, in B.F. Beck, ed., Sinkholes: their geology, engineering \& environmental impact. A.A. Balkema/Rotterdam/Boston.

Stucky-Electrowatt, J.V., 2000. Salman Farsi Dam Project, Mission Report, Tehran, Iran

Yuan, Daoxian 1990. The construction of underground dams on subterranean streams in South China karst. The Institute of Karst Geology, Guilin, China.
Dr. Petar Milanovic graduated from the Belgrade University in Yugoslavia in 1964. Received his PhD in Applied Karstology from Belgrade University in 1980. He worked at Karst Institute, Trebinje, Energoproject Hidroengineering Co, Belgrade and at Mostar University as Professor of Hydrogeology. The main research areas include geological engineering in karst related to dams, tunneling, grouting, water supply and groundwater protection. He has authored more than 60 professional papers and two books: Karst Hydrogeology published in US and Geological Engineering in Karst published in Yugoslavia.

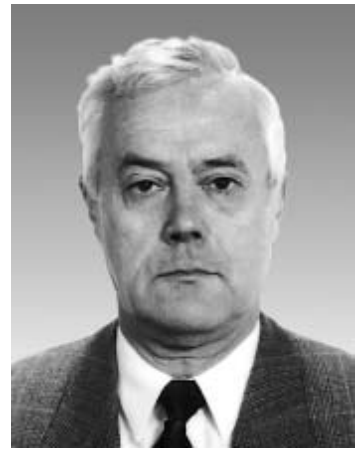

\title{
CALL FOR PAPERS
}

Episodes is the quarterly science and news journal of the International Union of Geological Sciences (IUGS). It focuses on the publication of results of scientific research and other information addressing issues of interest to the global earth-science community. Special emphasis is given to topics involving geological aspects of population growth and economic development and their resulting impacts on or implications for society. As the principal publication of the IUGS, Episodes also carries information about IUGS scientific programs and activities to the extent necessary to communicate effectively with the worldwide IUGS constituency.

Contributions of the following types of manuscripts are here solicited:

- review papers

- scientific articles

- conference reports

- news and views

- letters to editor

- book reviews

- information on training courses (especially those geared to participants from developing countries)

- noteworthy new publications, including national or regional geologic maps

Episodes also invites photos or other images for the front cover. Photos must be of high technical quality and tell an interesting geological story. A color transparency and one color print (at least $9 \mathrm{~cm} \times 12.6 \mathrm{~cm}$ ) are required for submission, which should be supplemented with a short explanatory paragraph (no more than 100 words).

Please address all contributions to:

\author{
The Editor \\ Episodes \\ P. O. Box 823, 26 Baiwanzhuang Road \\ 100037 Beijing, CHINA \\ Tel: +86-10-68320827; +86-10-68329084 \\ Fax: +86-10-68328928; \\ E-mail: episodes@public2.bta.net.cn.
}

